\title{
Towards a paradigm shift in occupational health
}

\author{
Citation for published version (APA):
}

de Brouwer, C. P. M. (2018). Towards a paradigm shift in occupational health: the potential of the International Classification of Functioning, Disability and Health (ICF) for preventive practice, research \& education. [Doctoral Thesis, Maastricht University]. Maastricht University. https://doi.org/10.26481/dis.20180222cdb

Document status and date:

Published: 01/01/2018

DOI:

10.26481/dis.20180222cdb

Document Version:

Publisher's PDF, also known as Version of record

\section{Please check the document version of this publication:}

- A submitted manuscript is the version of the article upon submission and before peer-review. There can be important differences between the submitted version and the official published version of record.

People interested in the research are advised to contact the author for the final version of the publication, or visit the DOI to the publisher's website.

- The final author version and the galley proof are versions of the publication after peer review.

- The final published version features the final layout of the paper including the volume, issue and page numbers.

Link to publication

\footnotetext{
General rights rights.

- You may freely distribute the URL identifying the publication in the public portal. please follow below link for the End User Agreement:

www.umlib.nl/taverne-license

Take down policy

If you believe that this document breaches copyright please contact us at:

repository@maastrichtuniversity.nl

providing details and we will investigate your claim.
}

Copyright and moral rights for the publications made accessible in the public portal are retained by the authors and/or other copyright owners and it is a condition of accessing publications that users recognise and abide by the legal requirements associated with these

- Users may download and print one copy of any publication from the public portal for the purpose of private study or research.

- You may not further distribute the material or use it for any profit-making activity or commercial gain

If the publication is distributed under the terms of Article $25 \mathrm{fa}$ of the Dutch Copyright Act, indicated by the "Taverne" license above, 


\section{Summary}



In the field of work and health three important changes can be observed in the last decades; 1. The number of older people in western populations is increasing rapidly, faster than the number of young people. This so-called aging and hazing of the population has, in combination with the higher life expectancy, consequences for the financing of pensions, since in most western countries the working population pays taxes to finance the pensions of the people already retired. Therefore the need to keep the working population healthy and motivated to work longer has increased.

2. The number of people working in the industrial sector in western societies has decreased, while the number of people working in the service sector has increased enormously. This change in work environment on population level results in a change in risk factors from merely chemical, biological, and physical in the industrial sector, towards organisational and psychosocial risk factors in the service sector. Therefore stress related conditions like coronary artery disease, burn-out, depression and other mental health complaints have become more prevalent in the working population.

3. The reintegration of employees sick for over four weeks (long term sickness absence) appears to be difficult in occupational healthcare practice, amongst others because work related risk factors often contribute to the development of sickness absence. Long term sickness absence (LTSA) constitutes a source of distress and social impairment for the employee and is also associated with high costs for employers and society. The risk of permanent work disability increases with the duration an employee is sick listed. In the last fifty years, legislation regarding sickness absence has changed drastically, resulting in approaches aiming to enhance work participation in an early stage of a sickness absence episode. These changes reduced the amount of people with permanent work disability significantly. Yet for preventing the development of episodes of long term sickness absence few initiatives have been developed so far.

Together, these developments are challenging for professionals in the field of work and health. The nature of the risk factors encountered changed and interventions preventing adverse outcomes regarding work participation should be applied earlier to keep the workforce in shape. Therefore a paradigm shift from post diagnosis tertiary care, in which the professional takes action when the employee is already sick listed (reactive workstyle), towards fostering the health of employees over the working-age lifespan is required. In this thesis an exemplary case of indicated prevention for future LTSA in occupational healthcare was used to investigate the challenges professionals in the field of work and health face when making a shift towards a more proactive work mode.

Changes in healthcare urge for changes in the education of healthcare professionals. In healthcare practice and healthcare curricula, the biomedical paradigm is still dominant, fostered by the wide use of the International Classification of Diseases and Health related problems (ICD) for registration, administration, communication, and billing in healthcare. 
For the domain of occupational health, the biopsychosocial paradigm seems a necessary alternative mental model. This thesis addresses the potential role of the International Classification of Functioning, Disability and Health (ICF) for enhancing the use of the biopsychosocial paradigm. The ICF embraces a broad concept of health of which functioning is the central component (see figure 1). Functioning in ICF terms is a universal human experience that can be conceptualized and classified from different perspectives: the perspective of the body (body functions and structures), the perspective of the individual (activities) and the perspective of society (participation, including labour participation).

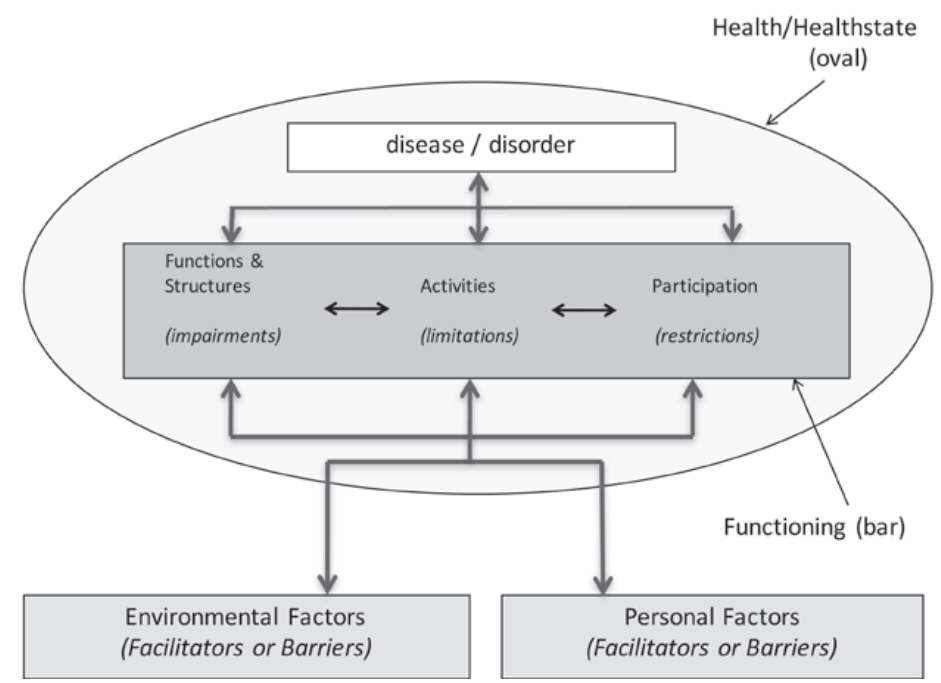

Figure 1 In the ICF the core element of health is functioning

Functioning can be influenced by a disease/disorder, but also by personal and environmental factors. The terms 'health' and 'health state' used in the ICF relate both to the (threatening) disease/disorder and to the functioning of the person. This is in accordance with the broad definition of health by the World Health Organisation (WHO). Moreover the ICF language is in line with important contemporary conceptualisations of health like for example positive health. Thus, professionals trained in ICF and engaged in the domain of occupational health might be able to use the ICF as a frame of mind, for example when delivering indicated and selective prevention strategies to their clients. Students trained in using the ICF in healthcare curricula can integrate the biopsychosocial paradigm in their mental models before entering practice. Furthermore they learn to reflect on health as a continuum in which fluctuations appear from time to time, instead of a state. 
Occupational healthcare professionals can potentially contribute greatly to population health by fostering the health of the working age population proactively. In chapter 2 . the professional perspective with regard to implementing an indicated preventive strategy comprising screening for increased risk for future long term sickness absence (LTSA), followed by a structured early consultation with an occupational physician (OP), was investigated. This revealed that delivery of the indicated preventive strategy by occupational healthcare professionals to office workers in a Dutch banking company with increased risk for future LTSA in the year following screening, encountered implementation problems. Through a case study the experiences of occupational health physicians delivering a structured early consultation as part of this preventive strategy, was investigated. A combination of structured interviews and surveys revealed that OP's were willing to focus more on prevention. Yet explaining the high risk for future LTSA to the employees with a score on the screenings questionnaire 'Balansmeter' above the cut-of level, was difficult. The 'Balansmeter' is based on a prediction model and captures 34 items measuring psychosocial (work) characteristics and (mental) health complaints. For the professionals the collection of discrete items in the 'Balansmeter' seemed not familiar to the concepts and diagnosis used in daily practice. Communicating the high risk message to the employees was also hindered by the unawareness of the latent stage of increased risk for LTSA on the side of the employees. Proactive preventive counseling of employees without a help seeking question, proved to be difficult as a starting point for the early structured consultation for the professionals. This approach was not in line with their former education, which, strongly rooted in the biomedical model, had trained them to start taking actions based on a concrete diagnosis when a health condition is already manifest. Being a health advocate clearly seems to be a different competency than being a medical expert. For mastering both competencies, the biopsychosocial model seems to be needed as a mental model too.

In chapter 3 the ICF framework was used to investigate the content validity of the screening questionnaire 'Balansmeter'. Through linking of the meaningful concepts captured in the items of the 'Balansmeter' to the ICF framework using the ICF linking rules, the fit of the screenings questionnaire with the biopsychosocial model was confirmed. A subsequent principal component analysis (PCA), showed a clustering of items in a limited amount of factors ( 8 for men, 9 for women), revealing a pattern behind the individual items predicting increased risk for future LTSA. When labelling these factors, work related environmental factors and personal factors, rather than a medical diagnosis, provided leads for preventing LTSA. Moreover this analysis can make the high risk status more comprehensible for the professionals involved in the preventive strategy. The relevance of the ICF framework for providing a common denominator in health measurement research was demonstrated with this study as well. As such it demonstrated the value of ICF as a common language in research and practice, which has the potential of increasing the health advocacy of professionals.

Work related environmental factors and personal factors (together contextual factors) are 
needed for describing, studying, and improving health in relation to work. This is especially relevant when the aim of occupational healthcare shifts towards more preventive approaches, like fostering the prevention of more diffuse stress related health conditions which are highly prevalent in contemporary work environments. In chapter 4 of this thesis, the contextual factors of the ICF were elaborated, aiming to improve the usability of the ICF in occupational health. Methods included a bottom up approach for inventorying the use of important environmental and personal factors amongst researchers and scholars, and a scoping review of the literature into the use of environmental and personal factors for occupational health. This endeavor resulted in a candidate list of detailed work related environmental factors and a candidate list of personal factors relevant for the field of work and health. So far the WHO did not develop a terminology specifying the personal factors because of their cultural sensitivity, and the fear that they can be misused as a 'classification' of the person through 'blaming the victim'. Yet, for the field of work and health, personal factors seem indispensable for a broad biopsychosocial needs assessment as a starting point for socio-medical consultation, and for tailoring of interventions to the personal needs of employees. The elaborated contextual factors are already being used by students, professionals, and researchers in the field of work and health, and they are published for stimulating the dialogue about their use and content.

The potential of the biopsychosocial model and the ICF for teaching and training in healthcare curricula is discussed in chapter 5. In this chapter, the design of an ICF based master program in the field of work and health, and the rationale for the choices made when developing this program were outlined in detail. In line with the pursued paradigm shift, the students of the master program Work, Health and Career at Maastricht University are educated and trained in using the biopsychosocial paradigm, including the ICF terminology and a broad conceptualization of health (see figure 1). Standalone ICF training sessions and application of ICF skills in Evidence Based Practice (EBP) training, during tutorial groups, and communication training, are the basis for the ICF based master program. Key elements in this approach are the broad biopsychosocial, ICF based, needs assessment as a starting point for analysing cases, alongside the use of a broad evidence base to substantiate cases. In order to take into account experiences, attitudes and values of stakeholders, besides quantitative outcome measures, the students learn to value a variety of methods rooted in different methodological paradigms. The pursued results are a shift from the biomedical towards the biopsychosocial paradigm, from a reductionist approach towards a holistic view on cases, from a reactive way of working towards a more proactive work style, and from using merely quantifiable evidence towards using a broad evidence base.

In chapter 6 the effects of two tailored ICF training programs on knowledge, skill and attitude of trainees were described. One program was designed and delivered for occupational health professionals working in two different occupational health services (OHS) in the Netherlands. The aim of this program was to enhance the implementation of a preventive strategy aiming for a reduction of LTSA in the target companies of the occupational health professionals, through 
screening and early intervention of employees at high risk for future LTSA (described in chapter 2). The other program was designed and delivered to students at Maastricht University following the master program Work, Health and Career (described in chapter 5). The aim of this program was to enhance students in using the ICF as a frame of mind and enhancing scientific reasoning from a biopsychosocial perspective through integrating the knowledge and skills acquired in the longitudinal ICF-training trajectory with knowledge and skills acquired in a longitudinal EBP training trajectory. The effectiveness of both ICF training programs regarding knowledge, skills and attitude was measured using the same instrument, in which the skills section comprised a case vignette adapted to the field of work and health. Both groups had almost equally low exposure to ICF prior to the ICF training program. After the ICF training program (T1) both groups showed a statistically significant increase in knowledge compared to the baseline measurement (T0), and the increase at T1 for the students compared to the professionals was significantly larger. Skills did not increase over time in the professionals, but did increase amongst the students. The perception on the usefulness of the ICF (part of attitude measurement) was high from the beginning in both groups and showed no increase after the ICF training program. The usefulness was perceived higher by students at both measurement moments T0 and T1. Perceived mastery (part of attitude measurement) increased to a great extend in both groups after training, but the increase was, statistically significant, larger in students at T1. Given the higher perceived usefulness of ICF amongst students and the statistically larger effects on knowledge, skills and mastery of the ICF, it can be concluded that healthcare curricula are the best place to stimulate the aforementioned paradigm shift for occupational health.

In the general discussion the 'systems framework', visualising the interdependency and complex interaction between the systems of health(care) and education, was used to relate the findings of the individual studies to each other. By teaching and training of the biopsychosocial paradigm, and integrating ICF in healthcare curricula, (future) professionals seem to be better equipped for meeting the healthcare demands in society. The effect of ICF training on knowledge, skills and attitude of professionals and students engaged in the domain of work and health are promising, since, according to social cognitive theories, they are strong predictors for the intention to change behavior, and as such strong indicators for the actual use of ICF skills in practice. The studies in this thesis show that for indicated prevention of contemporary health problems in occupational healthcare, like for example a high risk-status for future long term sickness absence, a broad biopsychosocial needs assessment is enabling for communicating the high risk message and for choosing a tailored intervention fitting the problems identified. Given the more pronounced effects of ICF training in students, healthcare curricula seem to be the best place for augmenting the pursued paradigm shift. Further research is needed to investigate the effect of ICF training on the actual behavior of professionals in healthcare practice, and the feasibility of ICF training in other curricula, to determine the adequate intensity of ICF training for professionals and students, and to assess whether ICF training ultimately results in professionals who are better equipped for encountering contemporary health problems. 

Samenvatting 

Op het gebied van werk en gezondheid hebben 3 belangrijke verandering plaatsgevonden in de laatste halve eeuw:

1. In westerse populaties is het aantal ouderen mensen sterk toegenomen ten op zichtte van de hoeveelheid jongere mensen. Deze zogenaamde vergrijzing en ontgroening van de populatie heeft, tezamen met de stijgende levensverwachting, gevolgen voor de financiering van pensioenen, omdat in de meeste westerse samenlevingen de werkende populatie door middel van belastingen het pensioengeld voor de gepensioneerde populatie financieren. Daarmee is de noodzaak om de werkende bevolking fit en gezond te houden sterk toegenomen, zodat ze langer deel kunnen blijven nemen aan het arbeidsproces.

2. In westerse populaties is het aantal mensen dat werkzaam is in de industrie sterk gedaald, terwijl het aantal mensen dat werkzaam is in de diensten sector enorm is gestegen. Op populatie niveau heeft deze verandering in werkomgeving geresulteerd in een verandering van arbeid gerelateerde risicofactoren van hoofdzakelijk fysiek, chemisch en biologisch van aard in de industrie, naar organisatie gebonden en (werk gerelateerde) psychosociale risicofactoren in de diensten sector. Daarmee zijn stress gerelateerde aandoeningen zoals hart en vaatziekte, burn-out, depressie en andere mentale gezondheidsklachten meer op de voorgrond gekomen bij de werkende bevolking.

3. Re-integratie van langdurig ziekteverzuim verloopt vaak moeizaam, onder andere omdat risicofactoren in de werkomgeving het verzuim vaak mede veroorzaakt hebben. Langdurig ziekteverzuim gaat gepaard met veel leed en sociale beperkingen voor de werknemer en gaat ook samen met hoge kosten voor de werkgever en de maatschappij. Het risico op blijvende arbeidsongeschiktheid neem toe met de duur van het ziekteverzuim. In de laatste vijftig jaar zijn er op het gebied van de wetgeving ten aanzien van langdurig ziekteverzuim en arbeidsongeschiktheid veel veranderingen doorgevoerd. Hierbij is steeds sterker het accent komen te liggen op participatie, door het ontwikkelen van interventies waarbij vroegtijdige re-integratie na uitval uit de werksituatie wordt nagestreefd. Deze veranderingen hebben ervoor gezorgd dat het aantal mensen dat arbeidsongeschikt wordt bevonden sterk is afgenomen. Echter tot op heden zijn er nauwelijks initiatieven die zich richten op het voorkomen van het ontstaan van langdurig ziekteverzuim.

Bij elkaar genomen vormen deze ontwikkelingen een uitdaging voor de professionals werkzaam op het gebied van werk en gezondheid. De aard van de risicofactoren waarmee ze in de praktijk te maken krijgen is sterk veranderd en interventies die kunnen worden benut om ongewenste uitkomsten te voorkomen, dienen eerder te worden ingezet om de werkende populatie in vorm te houden. Daarvoor is een paradigma verschuiving nodig van postdiagnostische tertiaire zorg, waarbij pas wordt gehandeld als de werknemer al uitgevallen is met ziekteverlof (reactieve werkwijze), naar het koesteren van gezondheid van werknemers gedurende hun arbeidzame leven. In dit proefschrift wordt een exemplarisch voorbeeld van geïndiceerde preventie ter voorkoming van toekomstig langdurig ziekteverzuim als voorbeeld 
genomen, om de uitdagingen te onderzoeken waarmee professionals op het gebied van werk en gezondheid geconfronteerd worden als ze moeten omschakelen naar een meer proactieve werkstijl.

Veranderingen in de zorg vragen veranderingen in het onderwijs van gezondheidsprofessionals. In de gezondheidszorgpraktijk en in curricula waarin gezondheidszorg professionals worden opgeleid, is het biomedische paradigma nog steeds leidend. Dit wordt mede veroorzaakt door het gebruik van de 'International Classification of Diseases and Health related problems (ICD) voor registratie, administratie, communicatie en declaratie doeleinden binnen de gezondheidszorg. Voor het domein van werk en gezondheid is het biopsychosociale paradigma een belangrijk alternatief denkkader. In dit proefschrift wordt de potentiële rol van de 'International Classification of Functioning, Disability and Health' (ICF) onderzocht, dat aansluit bij het biopsychosociale paradigma als denkkader.

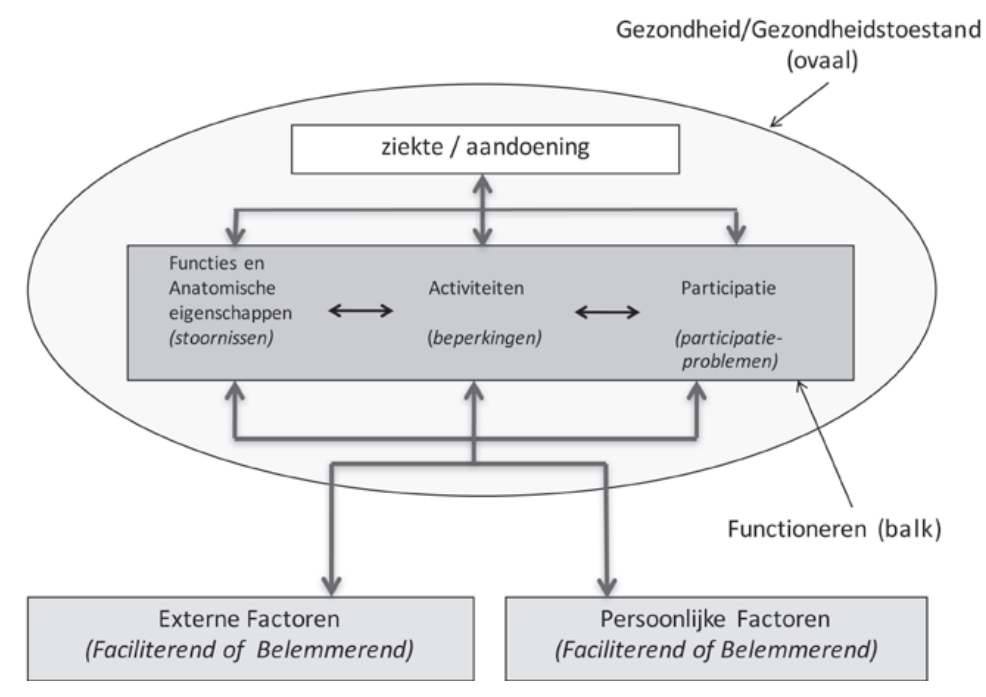

Figure 1 Functioneren staat centraal in het brede concept van gezondheid in de ICF

De ICF omarmt een breed concept van gezondheid, waarin functioneren centraal wordt gesteld (zie figuur 1). Hierbij wordt functioneren gezien als een universele menselijke ervaring die kan worden geconceptualiseerd en geclassificeerd vanuit diverse perspectieven; het perspectief van het lichaam (functies van het lichaam en anatomische eigenschappen), het perspectief van het individu (activiteiten) en het perspectief van de maatschappij (participatie, waaronder arbeidsparticipatie). Daarbij kan functioneren beïnvloed worden door een ziekte of aandoening, maar ook door persoonlijke en externe factoren. De term 
gezondheid en gezondheidstoestand zoals gebruikt binnen de ICF, verwijzen dan ook naar zowel een eventuele ziekte of aandoening als naar het functioneren van een individu. Dit is in overeenstemming met de brede definitie van gezondheid die wordt gehanteerd door de Wereld Gezondheid Organisatie (WHO). Daarnaast is het begrippenkader zoals gehanteerd binnen de ICF ook te gebruiken voor het beschrijven van meer recente conceptualisaties van gezondheid zoals positieve gezondheid. Het trainen in ICF van professionals op het gebied van werk en gezondheid kan het gebruik van het biopsychosociale paradigma als denkkader bevorderen, bijvoorbeeld bij het uitvoeren van geïndiceerde en selectieve preventieve strategieën. Studenten die worden getraind in het gebruik van de ICF binnen curricula op het gebied van gezondheid, kunnen het biopsychosociale paradigma als denkkader leren hanteren voor ze de praktijk ingaan. Bovendien leren ze denken in termen van gezondheid als een continuüm, waarin van tijd tot tijd bij iedereen fluctuaties optreden.

Professionals werkzaam in het domein van werk en gezondheid hebben de mogelijkheid om een grote bijdrage te leveren aan de publieke gezondheid, doordat ze de gezondheid van de werkende populatie proactief kunnen bevorderen. In hoofdstuk 2 wordt het perspectief van de professional met betrekking tot de implementatie van een preventieve strategie, waarbij werknemers werkzaam bij een grote bank in Nederland worden gescreend met de zogenaamde 'Balansmeter' op het hebben van een verhoogd risico op toekomstig langdurig verzuim, onderzocht. Medewerkers die volgens deze screeningsvragenlijst een verhoogd risico hebben op toekomstig langdurig verzuim worden uitgenodigd voor een consult waarin de mogelijkheden van sociaal medische begeleiding ter voorkoming van toekomstig verzuim besproken worden. Door middel van een case studie zijn de ervaringen van de bedrijfsartsen met het uitvoeren van dit preventieve consult in kaart gebracht. Aan de hand van vragenlijsten en interviews werd duidelijk dat de bedrijfsartsen graag meer preventief wilden werken. Echter, het uitleggen van de hoog-risico status m.b.t. toekomstig verzuim aan werknemers met een score boven het afkappunt op de 'Balansmeter' werd als moeilijk ervaren. De 'Balansmeter' is gebaseerd op een predictiemodel en bestaat uit 34 items (voorspellers van langdurig verzuim), die (psychosociale) werk karakteristieken en (mentale) gezondheidsklachten meten. Deze op het eerste oog arbitraire verzameling van items bleek niet goed te verbinden met de concepten en diagnosen waar de bedrijfsartsen mee werken in de dagelijkse praktijk. Communicatie over de hoog-risico status werd ook gehinderd door het lage bewustzijn ten aanzien van dit risico aan de kant van de werknemers. Een proactief preventief consult met werknemers die bij aanvang van het consult zelf nog geen concrete hulpvraag hebben geformuleerd, bleek een moeilijk startpunt voor de professionals te zijn. Deze aanpak is niet in lijn met hun vroegere opleiding die, sterk geworteld in het biomedische model, professionals traint om actie te ondernemen op een moment dat een concrete diagnose of aandoening aantoonbaar is. Gezondheidsbevorderaar blijkt daadwerkelijk een andere competentie te zijn dan medisch expert. Om beide competenties naast elkaar in de praktijk te kunnen uitvoeren lijkt het biopsychosociale model een belangrijk denkkader. 
In hoofdstuk 3 is de ICF gebruikt om de inhoudsvaliditeit van de screenings vragenlijst 'Balansmeter' te onderzoeken. Door middel van het met elkaar in verbinding brengen van betekenisvolle fragmenten uit de items van de 'Balansmeter' met ICF categorieën (een procedure die "linken" wordt genoemd), werd het biopsychosociale karaktervan de screenings vragenlijst bevestigd. In een factor analyse werden items uit de 'Balansmeter' geclusterd en werd een beperkt aantal factoren onderscheiden ( 8 voor mannen, 9 voor vrouwen). Hiermee werd duidelijk dat onder de afzonderlijke items in de 'Balansmeter' een patroon zit, waarbij persoonlijke en externe factoren, meer dan een medische diagnose, aanknopingspunten lijken op te leveren voor preventie van langdurig ziekteverzuim. Deze analyses maken het verhoogde risico op toekomstig langdurig verzuim, zoals gemeten met de 'Balansmeter', beter inzichtelijk voor de professionals. Bovendien wordt met deze studie het belang van de ICF als gezamenlijke noemer voor onderzoek naar de inhoud van meetinstrumenten, inzichtelijk gemaakt. Zo wordt de waarde van de ICF als gezamenlijke taal voor onderzoek en praktijkvoering zichtbaar, waarmee de competentie van gezondheidsbevorderaar versterkt kan worden.

Werk gerelateerde externe factoren en persoonlijke factoren (samen ook wel contextfactoren genoemd) zijn nodig bij het beschrijven, onderzoeken en verbeteren van werk gerelateerde gezondheid. Dit is zeker het geval als de focus verschuift naar meer preventieve benaderingen, waarbij het doel is om diffuse klachten, die veel gezien worden in de huidige praktijk van de bedrijfsgeneeskunde, te voorkomen. In hoofdstuk 4 wordt een uitbreiding van de werk gerelateerde contextfactoren beschreven, met als doel de bruikbaarheid van de huidige ICF voor het domein van werk en gezondheid, te vergroten. Daarvoor zijn de ervaring en behoefte aan het beschikbaar zijn van verder gespecificeerde context factoren in de ICF, onder een brede groep van onderzoekers en docenten werkzaam in het domein van werk en gezondheid, geïnventariseerd. Vervolgens is er een literatuur studie uitgevoerd naar externe en persoonlijke factoren in de literatuur over werk en gezondheid ('scoping review'). Dit heeft geresulteerd in een kandidaat lijst van werk gerelateerde externe factoren en een kandidaat lijst van persoonlijke factoren relevant voor het domein werk en gezondheid. Tot op heden heeft de WHO geen classificatie van persoonlijke factoren gepubliceerd, vanwege de culturele gevoeligheid en het mogelijke misbruik van zo'n classificatie. Echter voor het domein werk en gezondheid zijn de persoonlijke factoren onmisbaar bij het opstellen van een brede biopsychosociale behoefte inventarisatie, bijvoorbeeld bij sociaal-medische consultvoering en voor het afstemmen van interventies bij de persoonlijke behoefte van de werknemer. De uitbreiding op de contextfactoren zoals beschreven in dit proefschrift wordt reeds toegepast onder studenten, professionals en onderzoekers op het gebied van werk en gezondheid. Nu ze gepubliceerd zijn kunnen ze gebruikt worden om de verdere dialoog met betrekking tot gebruik en inhoud te stimuleren.

De mogelijkheden om het biopsychosociale model en de ICF te doceren en trainen binnen curricula in het domeinvan (werken) gezondheid wordtbesproken in hoofdstuk5. Het beschrijft 
in detail de ontwikkeling van een ICF gebaseerd master programma op het gebied van werk en gezondheid en de rationale voor de daarin gemaakte keuzes. In overeenstemming met de beoogde paradigmaverschuiving krijgen de studenten die het Engelstalige master programma 'Work, Health, and Career' volgen aan de Universiteit Maastricht, training en onderwijs in het gebruik van het biopsychosociale paradigma, inclusief de ICF terminologie en de brede conceptualisatie van gezondheid in de ICF (zie figuur 1). Op zichzelf staande ICF trainingen en gebruik van ICF vaardigheden tijdens training in 'Evidence Based Practice' (EBP), vormen, naast gebruik van de ICF in onderwijsgroep bijeenkomsten en communicatie training, het ICF fundament onder dit master programma. Kernelementen voor deze aanpak zijn de brede biopsychosociale, ICF gebaseerde behoefte inventarisatie bij aanvang van elke casus analyse, naast het benutten van een brede 'evidence base' voor de wetenschappelijke onderbouwing van casuïstiek. Om naast kwantitatieve uitkomstmaten ook ervaringen, attitude en waarden van belanghebbenden mee te kunnen nemen in de analyse, leren de studenten een scala aan methoden voortkomend uit verschillende methodologische paradigma's. Hiermee wordt een verschuiving bevorderd van het biomedische naar het biopsychosociale paradigma, van een reductionistische werkwijze naar een holistische benadering van cases, van een reactieve naar een proactieve werkwijze en van het overwegend gebruik maken van kwantificeerbare bewijslast naar het gebruik maken van een brede 'evidence base'.

In hoofdstuk 6 worden de effecten op kennis, vaardigheden en attitude van twee ICF training programma's beschreven. Een trainingsprogramma was op maat gemaakt voor de professionals van twee Arbodiensten in Nederland. Het doel van dit programma was om de implementatie van de preventieve strategie, welke tot doel heeft om langdurig ziekteverzuim te voorkomen in de bedrijven waaraan de professionals zorg leveren, te faciliteren. Het andere ICF trainingsprogramma was op maat gemaakt voor studenten die aan de Universiteit Maastricht het master programma 'Work, Health, and Career' volgen, zoals beschreven in hoofdstuk 5 van dit proefschrift. Het doel van dit programma was om de studenten te stimuleren de ICF als denkkader te gebruiken en om een wetenschappelijke denkwijze gebaseerd op het biopsychosociale perspectief te ontwikkelen. Hierin werden studenten getraind door de vaardigheden geleerd in het longitudinale ICF trainings-traject te integreren met de vaardigheden geleerd in het longitudinale EBP-trainingstraject. De effectiviteit van beide ICF trainingsprogramma's met betrekking tot kennis, vaardigheden en attitude ten aanzien van het gebruik van ICF, werden gemeten door gebruik te maken van een en hetzelfde meetinstrument, waarvan de vaardigheids-meting een casusbeschrijving passend bij het werkveld van arbeid en gezondheid omvatte. Beide trainingsgroepen hadden een gelijkwaardig laag niveau van bekendheid met de ICF voordat ze aan de ICF training deelnamen. Aan het eind van de ICF trainingstrajecten (T1) lieten beide groepen een statistisch significante toename in kennis zien in vergelijking met de meting voor aanvang van de training (TO), waarbij de stijging bij de studenten in vergelijking met de professionals significant groter was. Bij de professionals was geen toename in vaardigheden waarneembaar 
aan het eind van het trainingstraject, maar de studenten lieten wel een significante toename in vaardigheden zien. De perceptie over het nut van de ICF (onderdeel attitude meting) was vanaf het begin hoog in beide groepen en werd niet significant hoger aan het eind van de ICF trainingstrajecten. Daarbij werd het nut van de ICF zowel voor aanvang van de training (T0) als na afloop van het trainingstraject (T1) hoger gescoord door de studenten dan door de professionals. Het gevoel bekwaam te zijn in het gebruik van de ICF (onderdeel attitude meting) nam in beide groepen sterk toe door het trainingstraject, waarbij de toename bij de studenten gemeten op T1 statistisch significant groter was dan bij de professionals. Gezien de hogere scores door de studenten toegekend aan het nut van de ICF en de statistisch significante effecten op kennis, vaardigheden en gevoel van bekwaamheid in het gebruik van ICF in de studentgroep, kan geconcludeerd worden dat onderwijs curricula op het gebied van werk en gezondheid de aangewezen plaats zijn om een paradigmaverschuiving op gang te brengen.

In de algemene discussie wordt gebruik gemaakt van het 'systeem denkkader', dat de onderlinge afhankelijkheid en complexe interactie tussen de systemen van zorg en onderwijs visualiseert, om de studies in dit proefschrift met elkaar in verband te brengen. Door het doceren en trainen van het biopsychosociale paradigma en het integreren van de ICF in gezondheid gerelateerde curricula, kunnen (toekomstige) professionals beter voorbereid worden op de gezondheidsproblematiek die speelt in de maatschappij. De effecten van ICF training op kennis, vaardigheden en attitude bij professionals en studenten op het gebied van werk en gezondheid zijn veelbelovend, omdat in lijn met sociaal cognitieve theorieën deze effecten gezien kunnen worden als de voorspellers van gedragsverandering, wat in dit geval zou betekenen het daadwerkelijk gebruik van de ICF in de praktijk. De studies in dit proefschrift hebben laten zien hoe voor geïndiceerde preventie van hedendaagse werk gerelateerde gezondheidsproblemen, zoals de hoog risico-status voor toekomstig langdurig verzuim, een brede biopsychosociale behoefte inventarisatie gebaseerd op de ICF, problemen inzichtelijk kan maken. Ook het gebruik van een interventie op maat, die aansluit bij de geïdentificeerde problemen van de werknemer met een verhoogd risico op langdurig verzuim kan hiermee worden gefaciliteerd. Gezien de sterkere effecten van ICF training bij studenten, lijken gezondheid gerelateerde curricula de aangewezen plaats om de wenselijke paradigma verschuiving op gang te brengen. Verder onderzoek is nodig om de daadwerkelijke effecten van ICF training op het gedrag van professionals te onderzoeken, de haalbaarheid van ICF training in andere curricula te onderzoeken, te achterhalen wat een adequate intensiteit van training is voor professionals en studenten en te evalueren of ICF training uiteindelijk resulteert in professionals die beter geëquipeerd zijn voor de problematiek die ze tegenkomen in de praktijk. 